\title{
SOSIALISASI DIGITAL MARKETING DAN INOVASI PRODUK PADA UKM GULA MERAH GUNA MEMPERTAHANKAN EKONOMI DI MASA PANDEMI COVID-19
}

\author{
Dewi Diah Fakhriyyah*, Yuni Wulandari, Cindy Kharisma \\ Fakultas Ekonomi dan Bisnis, Universitas Islam Malang \\ *Korespondensi email: dewi_df@unisma.ac.id
}

\begin{abstract}
ABSTRAK
Berbagai permasalahan terkait menurunnya ekonomi UKM pada masa pandemi covid-19 saat ini memberikan dampak yang cukup signifikan bagi para pelaku UKM. Salah satu UKM yang terkena imbas pandemi adalah UKM pembuat gula merah di Desa Sarongan, Kecamatan Pesanggaran, Kabupaten Banyuwangi yang mengalami penurunan pendapatan. Puluhan atau ratusan masyarakat mendapatkan penghasilan dari memproduksi gula merah tersebut dan lalu menjualnya kepada pengepul. Untuk menstabilkan penjualan dan penghasilan masyarakat, kami membantu dengan memberikan sosialisasi edukasi yang melibatkan media digital. Pada tahap pertama kami melakukan sosialisasi pentingnya berbisnis pada masa pandemi Covid-19, ditujukan karena UKM masyarakat yang terdampak harus tetap berjalan dan stabil seperti sebelum adanya pandemi. Pada tahapan kedua, kami mengenalkan digital marketing kepada masyarakat agar digunakan sebagai media untuk memasarkan gula merah ke pasar yang lebih luas tanpa melalui pengepul. Diharapkan dengan sosialisasi ini masyarakat bisa bertransformasi ke digital bisnis untuk mendapatkan potensi penghasilan yang lebih banyak. Pada tahapan terakhir kami menjelaskan tentang pentingnya melakukan inovasi produk. Kami menjelaskan tentang pentingnya inovasi produk agar terdapat diversifikasi produk yang dapat menarik minat konsumen sehingga bisa bertahan ditengah persaingan di dalam digital bisnis. Diharapkan dengan sosialisasi ini dapat membuat pelaku UKM gula merah meningkatkan pendapatannya dan bertahan di tengah pandemi.
\end{abstract}

Kata Kunci: gula merah, pandemi covid-19, digital marketing.

\section{PENDAHULUAN}

Usaha Kecil dan Menengah (UKM) adalah usaha perdagangan yang dikelola oleh badan usaha atau perorangan yang merujuk pada usaha ekonomi produktif sesuai dengan kriteria yang ditetapkan oleh Undang-Undang Nomor 20 Tahun 2008 (Rizal, Mustapita, \& Kartika Sari, 2020). Menurut Kurniawan dalam Jauhari (2010), Usaha Kecil dan Menegah (UKM) merupakan salah satu bidang yang memberikan kontribusi yang signifikan dalam memacu pertumbuhan ekonomi Indonesia. Hal ini dikarenakan daya serap UKM terhadap tenaga kerja yang sangat besar dan dekat dengan rakyat kecil. Statistik pekerja Indonesia menunjukkan bahwa 99,5\% tenaga kerja Indonesia bekerja di bidang UKM.

Usaha Kecil dan Menengah (UKM) merujuk pada usaha ekonomi produktif yang berdiri sendiri, dilakukan oleh perseorangan atau badan usaha yang bukan merupakan anak perusahaan dengan kriteria aset sebesar Rp50 juta dan omzet di bawah Rp200 juta. Pengertian usaha kecil menengah dapat dilihat dari beberapa aspek. Dalam perekonomian Indonesia, sektor usaha kecil dan menengah memegang peranan penting, terutama bila dikaitkan dengan jumlah tenaga kerja yang mampu diserap oleh usaha kecil dan menengah 
tersebut. Selain memiliki arti strategis bagi pembangunan, usaha kecil menengah juga berfungsi sebagai sarana untuk memeratakan hasil-hasil pembangunan yang telah dicapai. Adapun yang menjadi bagian dari usaha kecil dan menengah adalah: sektor pertanian, sektor perdagangan, sektor perdagangan, sektor perdagangan, sektor pertambangan, pengolahan, sektor jasa, dan lainnya.

Sedangkan menurut Surat edaran Bank Indonesia No.26/I/UKK tanggal 29 Mei 1993 perihal Kredit Usaha Kecil (KUK) adalah usaha yang memiliki total asset Rp 60 juta (enam ratus juta rupiah) tidak termasuk tanah atau rumah yang ditempati. Pengertian usaha kecil ini meliputi usaha perseorangan, badan usaha swasta dan koperasi, sepanjang asset yang dimiliki tidak melebihi nilai Rp 600 juta (www.goukm.id).

Menurut Amiruddin (2018), perekonomian di Indonesia secara nasional menunjukkan bahwa kegiatan UKM merupakan usaha yang konsisten dan mampu berkembang. Dengan adanya krisis ekonomi yang melanda Indonesia sejak tahun 1997, UKM menjadi ujung tombak dan penyelamat perekonomian negara karena potensi UKM memberikan sumbangan terbesar dan signifikan pada Produk Domestik Bruto (PDB) dalam hal ini penyerapan tenaga kerja.

Menurut Pakpahan (2020), pandemi Covid-19 yang terjadi saat ini mau tidak mau memberikan dampak terhadap berbagai sektor. Pada tataran ekonomi global, pandemi Covid-19 memberikan dampak yang signifikan pada perekonomian domestik negara-bangsa dan keberadaan UKM. Indonesia yang didominasi oleh keberadaan UMKM sebagai tulang punggung perekonomian nasional juga terdampak secara serius, tidak saja pada aspek total produksi dan nilai perdagangan akan tetapi juga pada jumlah tenaga kerja yang harus kehilangan pekerjaannya karena pandemi ini. Dalam situasi pandemi ini, menurut Kemenkop UKM ada sekitar 37.000 UMKM yang memberikan laporan bahwa mereka terdampak sangat serius dengan adanya pandemi ini ditandai dengan: sekitar 56\% melaporkan terjadi penurunan penjualan, 22\% melaporkan permasalahan pada aspek pembiayaan, 15\% melaporkan pada masalah distribusi barang, dan 4\% melaporkan kesulitan mendapatkan bahan baku mentah. Masalah-masalah juga semakin meluas jika dikaitkan dengan adanya kebijakan Pembatasan Sosial Berskala Besar (PSBB) yang diterapkan di beberapa wilayah di Indonesia.

Pembatasan sosisal berskala besar menjadi kendala yang cukup besar bagi para pelaku UKM yang masih melakukan kegiatan jual-beli secara tradisional. Banyaknya permasalahan yang terjadi pada masa pandemi Covid-19 mengakibatkan UKM mengalami berbagai kendala dan menyebabkan penurunan aktivitas jual-beli serta distribusi yang terhambat sehingga berimbas pada penurunan pendapatan. Ketua Asosiasi UMKM Indonesia, Ikhsan Ingratubun, mengungkapkan pendapatan usaha UMKM "pupus" gara-gara wabah Covid-19, sehingga mereka kesulitan untuk membayar biaya-biaya dan gaji atau honor pekerja. Dampaknya adalah banyak dari pekerja UMKM terpaksa pulang kampung. "Akibat dari Covid-19, mengakibatkan pupus habis pendapatan per hari," (Amindoni, 2020).

Pendapatan yang menurun juga sangat dirasakan oleh pelaku UKM pembuatan gula merah yang ada di Desa Sarongan yang terletak di Kecamatan Pesanggaran Kabupaten Banyuwangi. UKM pembuatan gula merah di Desa Sarongan merupakan salah satu UKM yang dijadikan mata pencaharian utama oleh warga Sarongan. Hal ini karena mayoritas warganya bekerja sebagai pembuat gula merah. Gula merah yang dihasilkan oleh warga memiliki potensi yang cukup baik apabila dikelola dengan baik dan tepat. Namun karena kurangnya pengetahuan warga mengenai ilmu pemasaran sehingga seluruh kegiatan jualbeli masih dilakukan dengan metode konvensional/tradisional. Selain itu, pelaku UKM pembuatan gula merah tersebut juga masih memproduksi bentuk gula merah secara konvensional tanpa adanya inovasi produk. Sedangkan kondisi saat ini membuat penjualan 
menurun, oleh karena itu perlu dilakukan inovasi produk gula merah guna meningkatkan penjualan.

Dari permasalahan tersebut maka perlu adanya sosialisasi dan dan edukasi tentang ilmu pemasaran khususnya menggunakan digital marketing pada era sekarang yang telah memasuki era Revolusi Industri 4.0 pada pelaku usaha gula merah di Desa Sarongan. Digital Marketing adalah salah satu media pemasaran yang saat ini sedang banyak diminati oleh masyarakat untuk mendukung berbagai kegiatan yang dilakukan. Mereka sedikit demi sedikit mulai meninggalkan model pemasaran konvensional/tradisional beralih ke pemasaran modern yaitu digital marketing. Dengan jumlah pengguna social media yang banyak dan semakin hari semakin bertambah, dapat membuka peluang bagi UKM untuk mengembangkan pasarnya dalam genggaman smartphone (Pradiani, 2018). Dengan pemahaman menggunakan digital marketing akan memudahkan warga dalam melakukan pemasaran secara modern dan mudah dengan harapan UKM desa Sarongan dapat dikenal masyarakat lebih luas yang akan berdampak pada peningkatan penjualan.

Selain pengenalan digital marketing, edukasi mengenai inovasi produk pada pada produk UKM gula merah juga sangat penting dilakukan agar dapat memberikan nilai tambah atas produk tersebut sehingga dapat menambah pendapatan. Inovasi produk dapat diartikan sebagai upaya yang dilakukan pelaku usaha pembuat produk untuk memperbaiki, meningkatkan, dan mengembangkan produk yang diproduksi. Han dkk. dalam Curatman, Rahmadi, Maulany, \& Ikhsani (2016) menyebutkan bahwa tujuan utama dari inovasi produk adalah untuk memenuhi permintaan pasar sehingga produk inovasi merupakan salah satu yang dapat digunakan sebagai keunggulan bersaing bagi perusahaan.

Tujuan dilakukannya sosialisasi dan edukasi mengenai pemasaran melalui digital marketing dan inovasi produk pada pelaku UKM gula merah Desa Sarongan yaitu untuk meningkatkan pengetahuan masyarakat tentang teknik pemasaran online pada zaman sekarang yang mengikuti perkembangan zaman guna memperlancar arus perdagangan di desa Sarongan. Selain itu, tujuan pengenalan inovasi produk untuk menambah nilai jual dari gula merah yang akan menstabilkan penjualan produk tersebut. Pada akhirnya diharapkan sosialiasi ini akan meningkatkan pendapatan UKM khususnya pada era pandemi ini.

\section{METODE}

Target utama kami melakukan sosialisasi ini keberapa pelaku UKM gula merah yang ada di desa Sarongan dengan menyusun program kerja umum untuk membantu meningkatkan ekonomi UKM pada masa pandemi Covid-19 saat ini. Sebelum melakukan program kegiatan, kami melakukan survey terlebih dahulu dan telah diijinkan oleh kepala desa setempat. Tahap selanjutnya kami mulai melaksanakan proses sosialisasi dan edukasi yang sudah dijadwalkan sesuai rencana program kerja dengan tetap mematuhi protokol kesehatan, adapun beberapa pokok permasalahan yang dibahas dalam sosialisasi yang kita lakukan yaitu:

1. Pentingnya berbisnis pada masa pandemi Covid-19

2. Pemasaran produk melalui digital marketing

3. Edukasi dan sosialisasi inovasi produk guna mempertahankan ekonomi UKM pada masa pandemi Covid-19.

Sosialisasi yang kami lakukan difokuskan pada pelaku UKM gula merah yang berada di wilayah desa Sarongan RT/RW 002/003, mengacu pada peraturan pemerintah agar tidak membuat kerumunan pada masa pandemi sehingga kegiatan dilakukan dari rumah ke rumah dengan harapan mencegah penularan Covid-19 dan dapat meningkatkan perekonomian warga desa Sarongan khususnya pelaku UKM gula merah. 


\section{HASIL DAN PEMBAHASAN}

Selama beberapa hari melaksanakan program kerja, kami memperoleh hasil dari pengamatan di lapangan bahwa hampir semua pelaku UKM pembuatan gula merah belum melakukan inovasi pada produk mereka. Hal ini terjadi karena kurangnya pengetahuan masyarakat desa Sarongan tentang cara berbisnis yang tepat. Selain itu para pelaku UKM juga kesulitan dalam melakukan penjualan produk gula merah kecuali pada pengepul atau juragan. Oleh sebab itu, penjualan dilakukan dengan monopoli harga gula merah yang telah di tetapkan oleh pengepul, sehingga untuk menaikkan penghasilan sangat sulit.

Pada tahap pertama sosialisasi pentingnya berbisnis pada masa pandemi Covid-19 saat ini kami memberikan penjelasan yang rinci dan jelas agar mudah dipahami warga sekitar. Penggunaan bahasa yang santai dan bahasa sehari-hari pada saat sosialisasi menjadikan banyak warga mudah mengerti dan memahami apa itu bisnis dan seberapa penting melakukan bisnis pada saat ini. Antusiasme warga sangat membantu kesuksesan kegiatan pada tahap pertama ini.

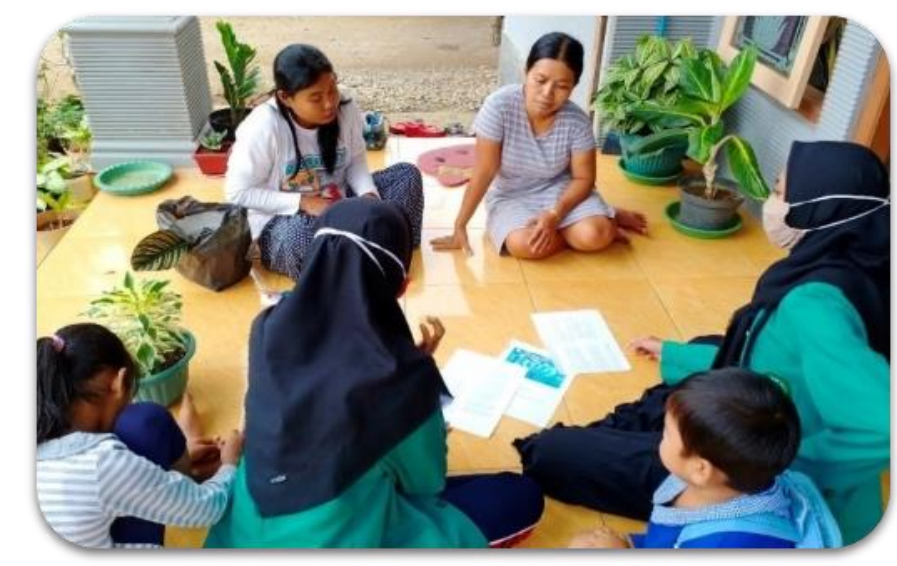

Gambar 1. Proses sosialisasi pentingnya berbisnis pada masa pandemi Covid-19 di Desa Sarongan.

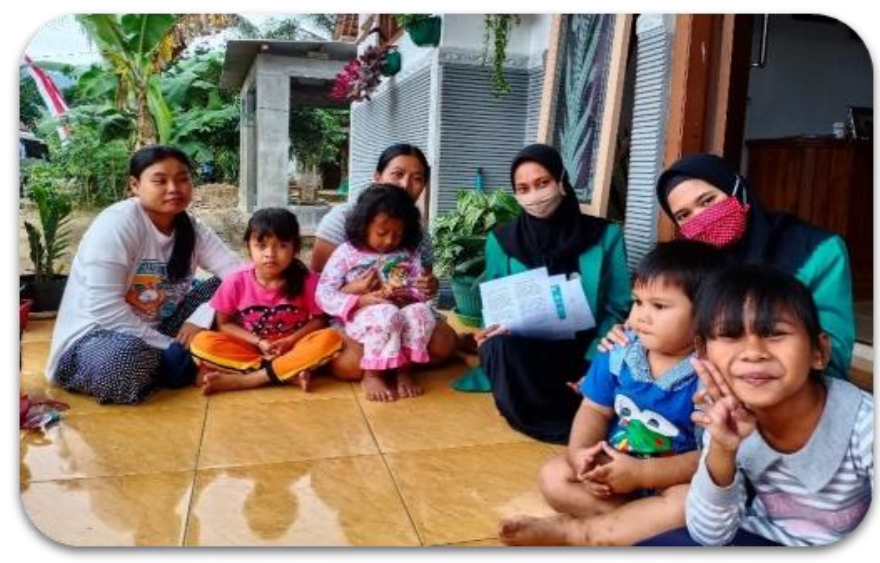

Gambar 2. Proses setelah dilakukan sosialisasi pentingnya berbisnis pada masa pandemi Covid-19 di Desa Sarongan

Tahap kedua yaitu sosialisasi mengenai transformasi digital sehingga pelaku UKM dapat menggunakan digital marketing untuk melakukan pemasarannya secara langsung. Pengetahuan tentang transformasi digital dirasa sangat penting mengingat perkembangan teknologi yang kian hari kian berkembang pesat. Dengan mengenal transformasi digital diharapkan pelaku UKM dapat mengembangkan usahanya melalui media digital agar lebih dikenal masyarakat luas. Dalam sosialisasi juga diberikan tips menjalankan sosial media marketing yaitu diantaranya: 
1. Membuat konten yang menarik.

2. Menyajikan produk yang inovatif.

3. Aktif dalam bersosial media seperti Facebook, dan Instagram, serta mengenalkan marketplace seperti Shopee dan Tokopedia.

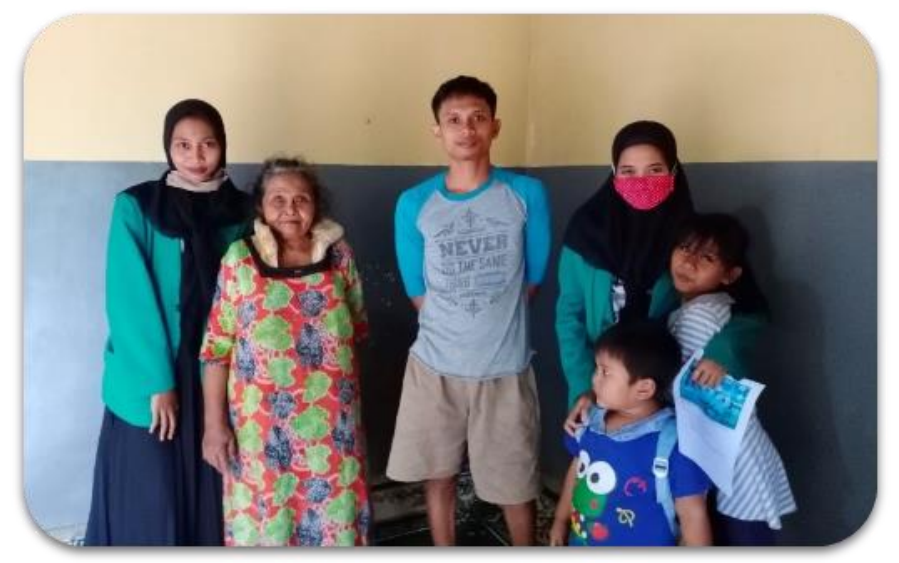

Gambar 3. Proses sosialisasi transformasi digital UMKM di Desa Sarongan.

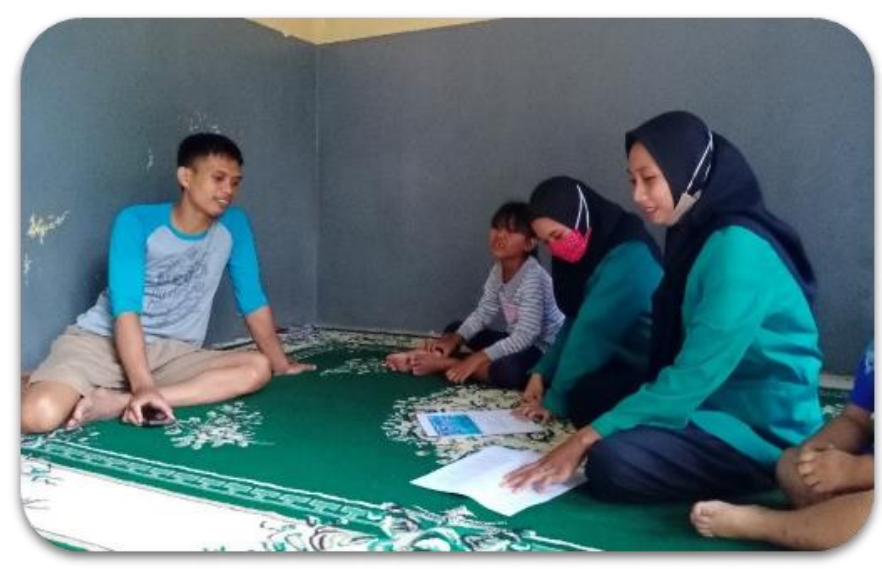

Gambar 4. Proses persiapan sosialisasi transformasi digital UMKM di Desa Sarongan

Selanjutnya tahapan terakhir adalah edukasi dan sosialisasi inovasi produk pembuatan gula merah guna mempertahankan ekonomi UKM pada masa pandemi Covid-19. Hasil produk yang tidak ada perubahan dan perkembangan sejak dulu pada UKM memberikan dampak seakan produk terlihat kuno dan tidak menarik. Sehingga kami berinisiatif untuk mengenalkan beberapa inovasi pada produk gula merah yang mungkin bisa diterapkan agar memberikan nilai lebih pada produk. Beberapa inovasi yang dapat di terapkan pada UMKM gula merah pada RT/RW 002/003 Desa Sarongan yaitu diantaranya:

1. Pembuatan gula merah non obat-obatan atau bahan kimia.

2. Pembuatan gula semut.

3. Pengemasan produk yang lebih menarik. Hal ini juga sangat penting karena semakin menarik suatu produk maka akan semakin banyak peminatnya. Pada gula merah pengemasan dilakukan mulai dari media percetakannya yaitu di bagi menjadi 2 ukuran. Pertama ukuran sedang dan kedua ukuran besar. Antara gula merah yang berukuran sedang dan besar dikemas dalam plastik yang berbeda dan disusun secara rapi kemudian ditutup dengan rapat. Sehingga kesan awal pada saat melihatnya yaitu menarik dan konsumen dapat membeli sesuai kebutuhan dengan menyesuaikan pada ukurannya. 


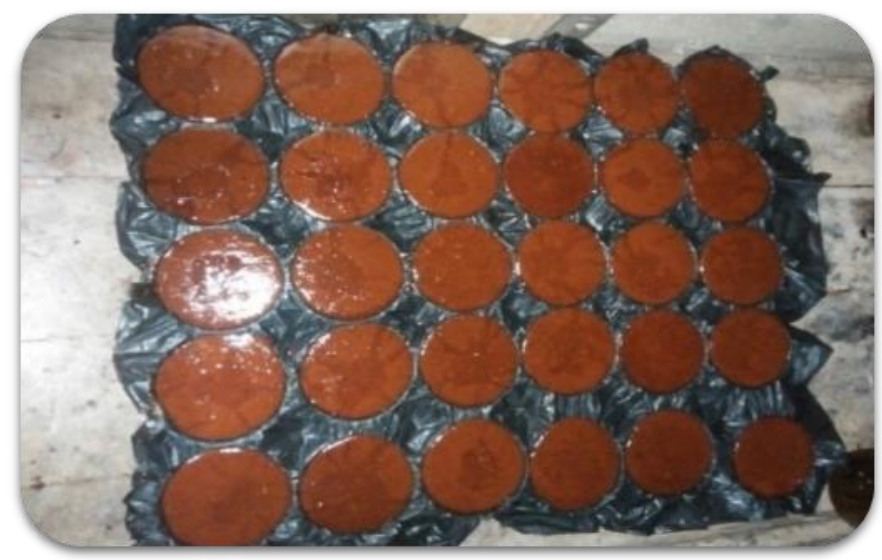

Gambar 5. Proses pencetakan gula merah non obat kimia

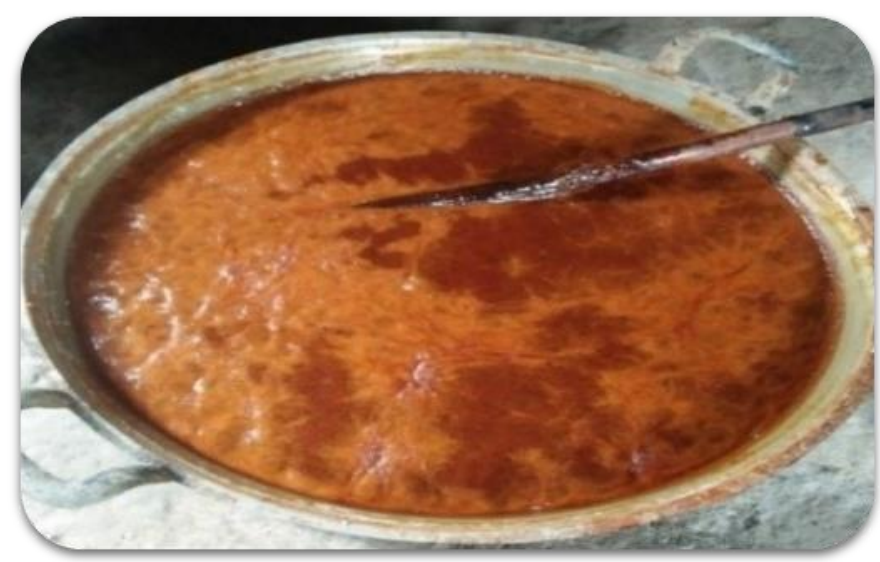

Gambar 6. Proses pengolahan gula merah non obat kimia UKM Desa Sarongan

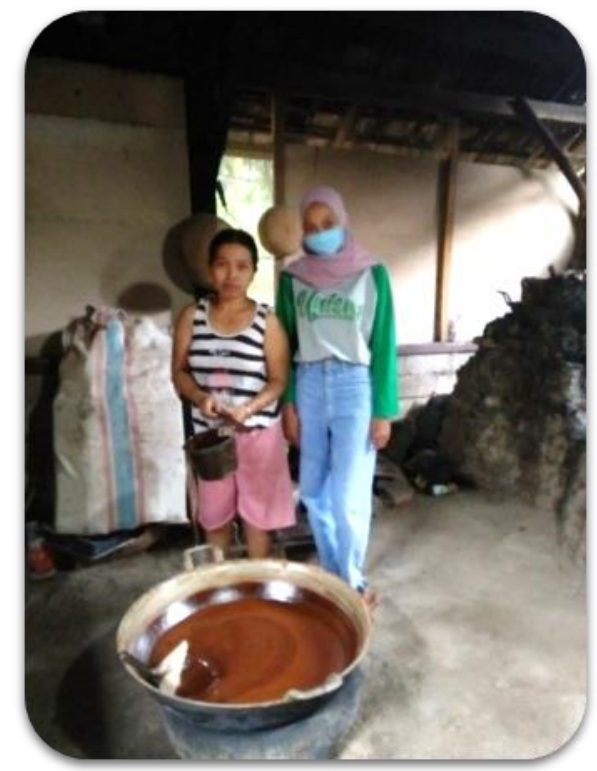

Gambar 7. Proses edukasi dan sosialisasi inovasi produk gula merah UKM Desa Sarongan

\section{KESIMPULAN}

Masih banyak masyarakat di Desa Sarongan, Kecamatan Pesanggaran, Kabupaten Banyuwangi yang belum memahami bagaimana cara berbisnis dengan tepat pada saat ini. Sehingga penghasilan yang diperoleh sulit untuk mengalami peningkatan ditambah adanya pandemi Covid-19 yang berdampak pada merosotnya perekonomian di Indonesia. Untuk 
mengatasi hal tersebut, kami melakukan sosialisasi dan edukasi mengenai bisnis UKM mulai dari pengenalan digital marketing hingga pembuatan inovasi produk. Setelah kegiatan ini, pelaku UKM menjadi lebih sadar akan pentingnya inovasi produk dan pemasaran melalui digital marketing. Faktor waktu, biaya dan keterbatasan ruang gerak di masa pandemi Covid-19 menjadi beberapa kendala yang kami hadapi untuk memaksimalkan program kerja kami, sehingga kami berharap untuk pengabdian di masa mendatang dapat memonitor hasil dari sosialisasi yang telah dilakukan serta merambah lebih banyak UKM.

\section{UCAPAN TERIMA KASIH}

Ucapan terima kasih bisa disampaikan kepada LPPM UNISMA yang memberikan kesempatan kepada kami untuk melakukan kegiatan KKN serta Kepala Desa Desa Sarongan, Kecamatan Pesanggaran, Kabupaten Banyuwangi yang telah memberi izin pada kami untuk melakukan pengabdian masyarakat.

\section{DAFTAR RUJUKAN}

Amindoni, A. (2020, March 30). Virus corona: Pendapatan usaha kecil "pupus" akibat covid 19, pemerintah siapkan bantuan sosial untuk pekerja harian. BBC News Indonesia. Retrieved from https://www.bbc.com/indonesia/indonesia-52059235

Amiruddin, A. (2018). Pemberdayaan Usaha Kecil Menengah (UKM) Binaan Dinas Perdagangan Kota Surabaya Dalam Upaya Meningkatkan Kesejahteraan. Repositori Universitas Airlangga. Universitas Airlangga. Retrieved from http://repository.unair.ac.id/id/eprint/74542

Curatman, A., Rahmadi, Maulany, S., \& Ikhsani, M. M. (2016). Analisis Faktor-faktor Pengaruh Inovasi Produk yang Berdampak pada Keunggulan Bersaing UKM Makanan dan Minuman di Wilayah Harjamukti Kota Cirebon. Jurnal Logika, 18(3), 61-75. Retrieved from http://jurnal.unswagati.ac.id/index.php/logika/article/view/263

Jauhari, J. (2010). Upaya Pengembangan Usaha Kecil dan Menengah (UKM) dengan Memanfaatkan E-Commerce. Jurnal Sistem Informasi, 2(1), 159-168. https://doi.org/10.1017/CB09781107415324.004

Pakpahan, A. K. (2020). Covid-19 Dan Implikasi Bagi Usaha Mikro, Kecil, Dan Menengah. Jurnal Ilmiah Hubungan Internasional, $0(0), \quad 59-64$. https://doi.org/10.26593/jihi.v0i0.3870.59-64

Pradiani, T. (2018). Pengaruh Sistem Pemasaran Digital Marketing Terhadap Peningkatan Volume Penjualan Hasil Industri Rumahan. Jurnal Ilmiah Bisnis Dan Ekonomi Asia, 11(2), 46-53. https://doi.org/10.32812/jibeka.v11i2.45

Rizal, M., Mustapita, A. F., \& Kartika Sari, A. F. (2020). Pelatihan Untuk Pengajuan Pembiayaan Mudharabah Perbankan Syariah Sebagai Peningkatan Kinerja UMKM. Jurnal Inovasi Hasil Pengabdian Masyarakat (JIPEMAS), 3(1), 15-22. https://doi.org/10.33474/jipemas.v3i1.2569 